\title{
Televizyon Dizilerinin Toplum Üzerindeki Etkisi (Karabük Örneği)
}

\author{
The Impact of TV Series on Society (The Example of Karabük)
}

\author{
Yusuf Sinan ZAVALSIZ ${ }^{a}$, Yüsra SOYDAŞ DAĞCI \\ a Dr. Öğr. Üyesi, Sağlık Bilimleri Üniversitesi, Hamidiye Sağlık Hizmetleri Meslek Yüksekokulu, Sosyal Hizmet ve \\ Danışmanlık Bölümü, e-Posta: sinanzavalsiz@hotmail.com, http://orcid.org/0000-0003-1291-0637/ \\ b Yüksek Lisans Öğrencisi, Karabük Üniversitesi Sosyal Bilimler Enstitüsü Sosyoloji Bölümü, \\ e-Posta: ysrasyds@gmail.com, http://orcid.org/0000-0001-5139-583X/
}

\begin{tabular}{cc}
\multicolumn{2}{c}{ Makale Bilgileri } \\
\hline Geliş Tarihi: & 04.04 .2019 \\
Kabul Tarihi: & 27.05 .2019 \\
Yayın Tarihi: & 26.06 .2019
\end{tabular}

\begin{abstract}
Özet
Yakın geçmişte hızla gelişmekte olan kitle iletişim araçları, toplumu doğrudan hedef alması sebebiyle sosyal değişmeyi derinden etkileyen faktörlerin başında gelmektedir. Kitle iletişim araçları amaca uygun kullanıldığında kültürün nesilden nesile aktarılmasını sağlayabilecek bir işleve sahiptir. Ancak yanlış kullanıldığında, özellikle çocukların ve gençlerin gelişiminde, dolayısıyla aile ve toplum yapisinda bozulmalara neden olabilmektedir.

Teknolojinin gelişmesiyle birlikte televizyon her eve girmiş, zamanla televizyon kanalları çoğalmaya başlamıştır. İlk televizyon yayınının 1928 yılında Amerika Birleşik Devletleri'nde gerçekleştiği düşünülürse, o günden bugüne kapitalizmin temel ilkelerinden biri olan rekabet, kendini medya alaninda da göstermiş, görsel medyayı hâkimiyeti altına almıştır. Medya, değişim içerisinde olan toplumu etkileyen en önemli aktörlerden biridir. Dolayısıyla görsel medya bugün başlı başına bir tüketim kültürü oluşturmaktadır. Tüketim kültürüne hizmet eden çok sayıda televizyon kanalının ilk sirada pazarladığı ürünse televizyon dizileridir. Türkiye'de televizyon yayınının ilk başladığı yıl 1968'dir. O tarihten itibaren televizyonlar her evde başköşeye oturtulmuş, evin bütün düzeni bu aletlere göre dizayn edilmiştir. 1986 yılına kadar tek kanaldan yayın yapılmıs, ancak bu tarihten sonra kanalların artıs hizını takip etmek mümkün olmamiştır. Televizyon ve özelde televizyon dizileri tamamen postmodern hayatın bir parçası haline gelmiştir. Diziler hayatın merkezinde yer almaya başladığından beri kültür, örf adet, alışkanlıklar, değerler, yaşam biçimi ve aile yapısı değişime uğramıştır.

Türk televizyonlarında yayınlanan dizilerin Türk toplum ve aile yapısına uygun olup olmadiğı, araştırmamızın en önemli sorusudur. Küçük bir kutuda yayınlanarak tüketilen bu sanal hikâyeler toplumumuzu nereye götürmektedir. Çalışma kapsamında televizyon dizilerinin Türk toplum yapısında ortaya çıkardiğı etkiler ele alınacaktır. Toplumun, televizyon dizileriyle birlikte değişen değerleri ile kapitalizmin aracı haline gelen görsel medyaya teslimiyeti ayrica irdelenecektir.

Araştırmada farklı yaş kategorilerinden 200 erkek, 200 kadın olmak üzere toplam 400 denek yer almıştır. Anket uygulanan denekler; 100 kadın, 100 erkek, 50 genç kadın, 50 genç erkek, 50 kız çocuk, 50 erkek çocuktur. Katılımcılar basit tesadüfï örneklem tekniğiyle Karabük halkından seçilmiştir.

Son yıllarda internetin yaygınlaşması, sosyal medyanın aşır kullanımı ile birlikte başta YouTube olmak üzere yeni video izleme platformları ortaya çıkmıştır. YouTube'da günde 1 milyar saatten fazla video izlenmesi, açlan kanallarda yayinlanan videoların televizyon dizileri gibi takip edilmesi, toplumu şekillendirme kabiliyeti tartışma götürmeyen ve milyonlarca kullanıcıya sahip olan televizyonun bundan sonraki süreçte tahtını internete kaptırabileceğine de işaret etmektedir.
\end{abstract}

Anahtar Kelimeler: Toplumsal Değişim, Televizyon Dizileri, Reklam, Tüketim. 


\section{Giriş}

İnsanlar arasındaki duygu, düşünce, bilgi ve haberlerin karş1lıklı olarak değişimine iletişim ad1 verilir. ${ }^{1}$ İnsanoğlu var olduğundan bu yana doğası gereği farklı insanlarla iletişim ve etkileşim içerisine girmiştir. Bireyler iletişim yoluyla kendilerini ifade eder, karşısındakini anlamlandırır ve ona ulaşmaya çalışır. İletişim sağlanırken birey ve çevre karşılıklı olarak bu durumdan etkilenir, zamanla değişime uğrar. ${ }^{2}$

İletişim, toplumsal hayatın sürdürülebilmesi açısından büyük öneme sahiptir. Bireyler arası ilişkilerin iletişim aracılığıyla oluşturulması ve toplumsal değerlerin sonraki nesillere aktarılabilmesi toplumun devamlılığını sağlar. Dolayısıyla iletişimsiz bir toplumun sürekliliği söz konusu değildir. ${ }^{3}$

Fichter toplumu, "ortak bir mekânda birlikte yaşayan, temel sosyal gereksinimlerini tatmin etmek için çeşitli gruplar içinde iş birliği yapan, ortak bir kültüre bağlı olan ve belli bir sosyal birim olarak işlevde bulunan kişilerin örgütlenmiş birliği” şeklinde tanımlar. ${ }^{4}$ Toplumu oluşturan bireyler, karş1lıklı olarak birbirine muhtaçtır. Gereksinimin giderilebilmesi ve yardım sağlanabilmesi için sahip olunan bilgi ve deneyimi paylaşmak zorundadırlar. ${ }^{5}$

Toplum sürekli bir değişim içerisindedir. Bu değişimde rol oynayan en önemli güçlerden biri de medyadır. Medyanın toplumları etkileme düzeyi aynı olmadığı gibi toplum içerisindeki bireyleri, aile içi ilişkileri etkileme düzeyi de farklılık arz edebilir. ${ }^{6}$

Günümüzde medya olarak tanımlanan kitle iletişim araçları, kullandığı dil ve görsel materyaller ile toplumsal olay ve olguları ifade etmektedir. ${ }^{7}$ Kitle iletişim araçları denildiğinde akla ilk gelenler televizyon, gazete, radyo, internet ve son y1llarda hizla yayginlık kazanan sosyal medyadır. 8 Böylece bilgi ve haber akışı kısa zamanda geniş kitlelere yayılmakta, bireylerin birbiriyle etkileşimi kolaylaşmaktadır. Dolayısıyla kitle iletişim araçları toplumsal yaşayış biçimlerini şekillendirme işlevine sahiptir. ${ }^{9}$

19. ve 20. yüzyılın getirdiği teknolojik gelişmelerle birlikte televizyon insan hayatına girmiş ve ilk yayın 1928 yılında Amerika'da gerçekleşmiştir. ${ }^{10}$ Türkiye'de ise ilk yayınlar 31 Ocak 1968'de haftada 3 gün üçer saat olarak başlamıştır. Televizyonun Türkiye'ye gelişinin 10. yılında PTT merkezlerine kayıtlı televizyon alıcı sayısı 2.250.000'e ulaşmıştır. Yayın saatleri artmaya devam etmiş ve 31 Aralık 1981 yılbaşı gecesinden itibaren televizyon renkli yayın hayatına adım atmıştır. ${ }^{11}$

1986 yılında TRT-2 yayın hayatına girmiş ve böylece yerli kanal sayısı ikiye yükselmiştir. Akabinde gelişmeler çok hızlı seyretmiş ${ }^{12}$, günümüzde bu rakam yüzlerle ifade edilir hale gelmiștir. ${ }^{13}$ İlk yerli televizyon dizisi 1974 yılında Kaynanalar adıyla TRT'de yayınlanmıştır. Bir sonraki yıl Aşk-1 Memnû dizisi 6 bölüm olarak izleyicinin beğenisine sunulmuştur. Ancak gerçek kitleselliğe 1986 yılında TRT-2'de yayınlanan Perihan Abla dizisiyle ulaşılmıştır. Bu yıllar aynı zamanda TRT’nin izleyiciye birçok yabancı dizi sunduğu dönemlerdir. Özel televizyonların yayın hayatına girmesiyle dizi sektörü ivme kazanmıştır. Yerli televizyon dizileri, haber programlarından sonra en çok tercih edilen programlar olmuş, geniş kitlelerin ilgisini çekmiştir. Dolayısıyla talebi karşılamak adına dizi sayısında sürekli bir artış gözlenmiştir. ${ }^{14}$

Postmodern dönemde bireyler medyanın etkisiyle daha çok tüketmeye sevk edilmektedir. Bunun gerçekleşmediği durumlarda ise mutsuzluk ortaya çıkmakta ve bu his

\footnotetext{
${ }^{1}$ David Crowley \& Paul Heyer, İletişim Tarihi, Çeviren: Berkay Ersöz, Ankara 2014, s. 18.

2 Ayseli Usluata, İletişim, İstanbul 1997, s. 5.

3 Atilla Girgin, Uluslararası İletişim, İstanbul 2002, s. 1.

4 Joseph Fichter, Sosyoloji Nedir?, Çeviren: Nilgün Çelebi, Ankara 2011, s. 88.

5 A. Haluk Yüksel, “İletişimin Toplumsal Boyutu Olarak Kitle Illetişimi”, Kurgu Dergisi, 1990 (7), s. 11.

${ }^{6}$ Mehmet Özdemir, İlköğretim Öğretmenlerinin Aile Değerleri ve Medyanın Aile Değerlerine Etkisi Hakkındaki Görüssleri, Yeditepe Üniversitesi Sosyal Bilimler Enstitüsü Eğitim Yönetimi ve Denetimi Ana Bilim Dalı, Yayınlanmamış Yüksek Lisans Tezi, İstanbul 2009, s. 21.

7 Ahmet Oktay, Medya ve Hedonizm, İstanbul 1995, s. 169.

8 Mehdi Keskin, Görsel Medya ve Kamuoyu İlişkisi: Televizyonda Siyasi Tartışma Programlarının Söylem Analizleri, Maltepe Üniversitesi Sosyal Bilimler Enstitüsü Sosyoloji Ana Bilim Dalı, Yayınlanmamış Yüksek Lisans Tezi, İstanbul 2015, s. 5.

9 Ceyda Ilgaz Büyükbaykal, “Kitle İletişim Araçları ve Toplumsal Yaşam”, İstanbul Üniversitesi İletişim Fakültesi Dergisi, 2005 (21), s. 71.

10 Ünsal Oskay, Toplumsal Gelişmede Radyo ve Televizyon, Ankara 1971, s. 17.

11 http://www.trt.net.tr/Kurumsal/Tarihce.aspx, Erişim Tarihi: 25.12.2016.

12 http://www.trt.net.tr/Kurumsal/Tarihce.aspx, Erişim Tarihi: 26.12.2016.

13 Bu konuda bkz. Hülya Uğur Tanrı̈̈ver, Türkiye'de Televizyon Yayıncılığı 2011, İstanbul 2012 , s. 15.

14 Tanriöver, Türkiye'de Film Endüstrisinin Konumu ve Hedefleri, İstanbul 2011, s. 45.
} 
farklı bir şeyin tüketilmesiyle giderilmektedir. ${ }^{15}$ Postmodern dönemin getirileriyle birlikte değişen, dönüşen tüketim kavramı medyayla yakından ilişkilidir. Medya sektörünü elinde tutanlar, toplumun parçalanmış kimliklerine ayrı ayrı hitap edebilecek çeşitli televizyon programları hazırlamaktadır. ${ }^{16}$ Farklılıkların ve çeşitliliklerin ön planda tutulduğu bu dönemde bireylerin ilgi alanlarına hizmet edecek tematik kanallar artış göstermiştir. ${ }^{17}$ Tematik yayınc1lıkla toplumun yaş, cinsiyet gibi kriterlerden ziyade moda, müzik, alışveriş, belgesel, spor gibi daha alt başl1klarda bir araya getirilmesi hedeflenmiştir. Bireysel izleyiciliği teşvik etmesi yönüyle tematik kanallar, aile kavramına zarar vermektedir. ${ }^{18}$

\section{Televizyonun Toplumsal İşlevi}

Kitle iletişim araçları arasında yaygın olarak kullanılan televizyon, toplum içerisinde belli işlevlere sahiptir. Bunların başında haber verme özelliği gelmektedir. Bilgilerin yayılması toplumsal iletişim açısından oldukça önemlidir. Televizyon, haber vermenin hemen ardından bireylere sunduğu programlarla bir eğitim aracı olarak karşımıza çıkmaktadır. Günümüzde birçok şeyin televizyon aracılığıyla kısa sürede öğrenilebilir duruma gelmesi eğitsel işlevinin bir göstergesidir. Üçüncü sırada ise eğlendirme özelliği göze çarpmaktadır. Ucuz ve kolay ulaşılabilir olması izleyicinin serbest zaman geçirmek adına tercihini belirlemektedir. Eğlence ve show programları, aynı zamanda dizi filmler, bu işleve hizmet eder. Bir diğer işlevi ise mal ve hizmetlerin tanıtılmasıdır. Yayınlanan programların pek çoğunda sanal reklamlar yer alır. Son olarak inandırma ve harekete geçirme işlevi karşımıza çıkar ki; bu ikisi haber verme ve reklam özellikleriyle bağdaşmaktadır. Haber verme özelliği inandırma isteği üzerine kuruludur. Reklam politikaları ise kitleleri etkileme ve ürünü pazarlama anlayışıla donatılmıștır. 19

Radyo ve Televizyon Üst Kurulu'nun kararıyla reyting ölçümlerini Televizyon İzleme Alışkanlıkları Anonim Şirketi üstlenmiştir. Şubat 2017 ölçümlerine göre, gün içerisinde en çok izlenen yerli kanal ATV olmuştur. Onu SHOW TV takip etmektedir. Hemen arkasından sırayla KANAL D, STAR TV, TV8 ve FOX en çok izlenen kanallar arasında yer almıştır. ${ }^{20}$

Așağıdaki tabloda 2017 Şubat ayı total reyting sonuçlarına yer verilmiștir. ${ }^{21}$

\begin{tabular}{lllccc}
\hline Sira & \multicolumn{1}{c}{ Program Ad1 } & Kanal Ad1 & $\begin{array}{c}\text { Toplam } \\
\text { Reyting }\end{array}$ & $\begin{array}{c}\text { Yayın } \\
\text { Sayıs }\end{array}$ & $\begin{array}{c}\text { Bölüm } \\
\text { Reytingi }\end{array}$ \\
\hline 1 & Diriliş Ertuğrul & TRT 1 & 50,84 & 4 & 12,71 \\
2 & Eşkıy Dünyaya Hükümdar & ATV & 39,29 & 4 & 9,82 \\
& Olmaz & & & & \\
3 & Arka Sokaklar & KANAL D & 37,78 & 4 & 9,45 \\
4 & İçerde & SHOW TV & 37,10 & 4 & 9,28 \\
5 & Kirgın Çiçekler & ATV & 36,71 & 4 & 9,18 \\
6 & Assk ve Mavi & ATV & 33,46 & 4 & 8,37 \\
7 & Survivor & TV8 & 162,74 & 21 & 7,75 \\
8 & Anne & STAR TV & 30,82 & 4 & 7,70 \\
9 & Kalbimdeki Deniz & FOX TV & 25,91 & 4 & 6,48 \\
10 & Vatanım Sensin & KANAL D & 19,42 & 3 & 6,47 \\
11 & Cesur ve Güzel & STAR TV & 22,99 & 4 & 5,75 \\
12 & Kara Sevda & STAR TV & 22,81 & 4 & 5,70 \\
13 & No: 309 & FOX TV & 22,79 & 4 & 5,70 \\
14 & Müge Anlı ile Tatlı Sert & ATV & 99,72 & 20 & 4,99 \\
15 & Ad1 Efsane & KANAL D & 19,66 & 4 & 4,91 \\
16 & Umuda Kelepçe Vurulmaz & FOX TV & 9,47 & 2 & 4,73 \\
17 & O Hayat Benim & FOX TV & 17,40 & 4 & 4,35 \\
\hline
\end{tabular}

${ }^{15}$ Ali Kuzu \& Hanife Özveren, “Tüketilen Tüketici”, Sakarya Üniversitesi Fen Edebiyat Fakültesi Dergisi, 2011 (1), s. 65.

16 Tahir Karaboğa, "Bir Kitle İletişimsizlik Aracı Olarak Televizyon”, Sosyoloji Notları Dergisi, 2007 (3), s. 26.

17 Emine Sayllgan, "Medya Sektöründe Bir Uzmanlaşma Olgusu Olarak Tematik Kanallar ve İzleyici Çeşitliliğinin Tematik Kanal Oluşumundaki Rolü”, Gümüşhane Üniversitesi İletişim Fakültesi E-Dergisi, 2014 (3), s. 6.

18 Mihalis Kuyucu, “Türkiye'de Tematik Tv Yayıncılı̆̆ı Gençlerin Tematik Televizyon İzleme Alışkanlıklarının Televizyon Yayıncılığına Olan Yansımaları", International Journal of Social Science, 2015, 32 (3), s. 251.

${ }_{19}$ Aysel Aziz, Radyo ve Televizyona Giriş, Ankara 1981, ss. 51-55.

20 http://www.tiak.com.tr/raporlar/2017/Subat2017.htm, Erişim Tarihi: 20.03.2017.

${ }_{21}$ http://www.reytingsonuclari.com/2017/3/subat-ayi-aylik-reyting-sonuclari-subat-2017-h2372.html, Erişim Tarihi: 20.03 .2017$. 
Televizyon Dizilerinin Toplum Üzerindeki Etkisi (Karabük Örneği) - Yusuf Sinan ZAVALSIZ, Yüsra SOYDAȘ DAĞCI

\begin{tabular}{llllcc}
\hline 18 & Hayat Şarkısı & KANAL D & 17,35 & 4 & 4,34 \\
19 & Hayat Bazen Tatlıdır & STAR TV & 17,32 & 4 & 4,33 \\
20 & Cesur Yürek & SHOW TV & 12,94 & 3 & 4,31 \\
21 & Esra Erol'da & ATV & 84,35 & 20 & 4,22 \\
22 & Evleneceksen Gel & SHOW TV & 83,86 & 20 & 4,19 \\
23 & Zuhal Topal'la & STAR TV & 80,41 & 20 & 4,02 \\
24 & Güldür Güldür Show & SHOW TV & 15,61 & 4 & 3,90 \\
25 & Paramparça & STAR TV & 15,55 & 4 & 3,89 \\
\hline
\end{tabular}

Tabloda görüldüğü üzere 2017 Şubat ayında en çok takip edilen televizyon programı aylık 50,84 izlenme oranıyla Diriliş Ertuğrul dizisi olmuştur. ATV'de yayınlanan Eşkıya Dünyaya Hükümdar Olmaz adlı dizi ise ikinci sırada yer almaktadır. Üçüncü sırada 400 bölümden fazla yayınlanan Arka Sokaklar bulunmaktadır. Dolayısıyla en çok izlenen televizyon programlarının başında diziler gelmektedir.

Televizyon Dizileri ve Reklam Kültürü

Televizyon dizileri, içerisinde ana karakterler ve çok sayıda yan karakter bulunan, çoğunlukla ana karakter etrafında gerçekleşen olayları anlatan televizyon programlarıdır. Dizilerde olay örgüsü sürekli bir akış halinde devam eder. İzleyiciyi bu akış içinde tutmak için dizide kendisini bulacağı bireysel hayatlar sunulur. ${ }^{22}$

Ayrıca dizi sektörünün oldukça maliyetli olması, dizi yapımcılarını üretim maliyetlerini düşürmek adına programın içine ürün yerleştirmeye ve araya reklam almaya yöneltmiştir. Ürün yerleştirme, film ve dizilerde görsel ya da işitsel olarak tüketiciye rahatsılılk vermeden marka ve logolarla ürünün tanıtılmasıdır. ${ }^{23}$ Medyanın ürettiği metin ya da nesneler tüketim kültüründe farklı anlamlar taşımaktadır. Bunun kitlelere aktarımı ise televizyon dizileri ve reklamlar aracılı̆̆ıla sağlanır. ${ }^{24}$

Günümüzde tüketim farklı bir boyut kazanmış, ihtiyaçları karşılamaktan ziyade bireyin toplumdaki konumunu belirler hale gelmiştir. Bir diğer ifadeyle tüketimin boyutu; sosyal, ekonomik ve kültürel açıdan bireyi tanımlamaktadır. Tüketici bu şekilde zenginliğini göstermeyi, d1ş görünüşüyle ve tükettiği nesnelerle toplumda statü sahibi olmay1 amaçlar. ${ }^{25}$ Modern dünyada buna başarı kültürü adı verilmektedir.

Reklam, tüketici alışkanlıklarıyla doğrudan ilişkilidir. Bir ürünü veya hizmeti tanıtırken tüketiciye belli mesajlar yollaması bakımından reklam başlı başına bir kitle iletişim aracıdır. Ürünün tüketiciye tanıtılması amacının yanı sıra, alıcı kitleden daha büyük bir hedef kitleye ulaşmak istemesi bakımından reklam belli mesajlar içermektedir. ${ }^{26}$ Dizilerin içerdiği ürün yerleştirmeler ve reklamlar, ürünlerin pazarlanmasında tüketiciye "zatenlik" hissi yaşatma üzerinden yola çıkar. Tüketici ürüne "zaten” ihtiyacı varmış gibi veya kendisinin kesinlikle sahip olması gerektiği bir nesneymiş gibi bakmaya başlar. ${ }^{27}$ Ürüne veya hizmete sahip olamadığında ise yoksunluk hissi yaşar. Reklamlar bu şekilde bireylerin sahip olma güdülerini ortaya çıkararak onları etkisi altına alır, yeni ihtiyaç ve tüketim alanları yaratırken bireyin zatenlik hissini besler; ekonomik, sosyal ve psikolojik anlamda tüketiciyi yönlendirir. ${ }^{28}$

\section{Araştırma Bulguları}

Tablo-1: Cinsiyet

\begin{tabular}{lcc}
\hline Cinsiyet & Kişi sayısı & Yüzde \% \\
\hline Kadın & 200 & 50 \\
Erkek & 200 & 50 \\
Toplam & $\mathbf{4 0 0}$ & $\mathbf{1 0 0}$ \\
\hline
\end{tabular}

Çalışmamızda yer alan kadın ve erkek denekler birbirine eşittir. 400 deneğin 200'ü (\%50) kadınlardan, 200’ü (\%50) erkeklerden oluşmaktadır.

\footnotetext{
22 http://www.enfal.de/tele.htm, Erişim Tarihi: 08.01.2017.

${ }^{23}$ Vesile Çakır \& Edanur Kınıt, “Televizyon Dizilerinde Ürün Yerleştirme ve Sponsorluğun Sonuçları", Global Media Journal Turkish Edition, 2009 (5), s. 21.

24 Seda Hasekioğlu, Reklam ve İdeoloji: Yazılı Basında Yer Alan Reklamlara Göstergebilimsel Bir İnceleme, Ankara Üniversitesi Sosyal Bilimler Enstitüsü Gazetecilik Anabilim Dalı, Yayınlanmamış Yüksek Lisans Tezi, 2008, s. 30 .

25 Hasekioğlu, s. 7.

26 Jean Baudrillard, Tüketim Toplumu, İstanbul 2004, s. 157.

27 Judith Williamson, Reklamların Dili-Reklamlarda Anlam ve İdeoloji, Ankara 2000, s. 48.

${ }^{28}$ Filiz Ertunç, Çocuk Dünyasında Reklamın Rolü: Televizyon Reklamlarında Çocuklara Yönelik Düzenlemeler, Radyo ve Televizyon Üst Kurulu Yayınlanmamış Uzmanlık Tezi, Ankara 2011, s. 21.
} 
Tablo-2: Yaş

\begin{tabular}{lcc}
\hline Yaş & Kişi sayıs & Yüzde \% \\
\hline $12-18$ & 100 & 25 \\
$19-25$ & 150 & 37.5 \\
$26-45$ & 100 & 25 \\
$45+$ & 50 & 12.5 \\
Toplam & $\mathbf{4 0 0}$ & $\mathbf{1 0 0}$ \\
\hline
\end{tabular}

Katılımcıların yaş dağılımı incelendiğinde \%25’inin 12-18, \%38²9’inin 19-25, \%25’inin 26-45 yaş aralığında olduğu görülmektedir. \%13'lük bir grup ise 45 yaş üstünde yer almaktadir.

Tablo-3: Eğitim Durumu

\begin{tabular}{lcc}
\hline Eğitim & Kişi sayıs & Yüzde $\%$ \\
\hline Okur-yazar & 9 & 2,3 \\
İlkokul & 36 & 9 \\
Ortaokul & 16 & 4 \\
Lise & 130 & 32,5 \\
Ön lisans & 13 & 3,3 \\
Lisans & 192 & 48 \\
Yüksek lisans ve üzeri & 4 & 1 \\
Toplam & $\mathbf{4 0 0}$ & $\mathbf{1 0 0}^{\mathbf{3 0}}$ \\
\hline
\end{tabular}

Deneklerin yarıya yakını (\%48) lisans mezunu ya da öğrencisidir. İkinci sırada lise seviyesindeki (\%33) katılımcılar bulunmaktadır. Daha sonra ilkokul (\%9), ortaokul (\%4), ön lisans (\%3), yüksek lisans (\%1) düzeyinde eğitime sahip olanlar sıralanmaktadır. Deneklerin $\% 2$ 'si okur yazar durumdadir.

Tablo-4: Gün İçinde Televizyon Başında Geçirilen Süre

\begin{tabular}{lcc}
\hline Televizyon izleme & Kişi sayıs & Yüzde \% \\
\hline $0-2$ & 207 & 51,7 \\
$2-4$ & 109 & 27,3 \\
$4-6$ & 66 & 16,5 \\
$6-8$ & 10 & 2,5 \\
$8+$ & 7 & 1,8 \\
Cevaps1z & 1 & 0,3 \\
Toplam & $\mathbf{4 0 0}$ & $\mathbf{1 0 0}$ \\
\hline
\end{tabular}

Deneklerin yarısından çoğu (\%52) günde 0-2 saat arası televizyon izlediğini beyan etmiştir. \%27'si 2-4 saat, \%17'si 4-6 saat, \%3'ü 6-8 saat arası televizyon izleme alışkanlığına sahiptir. Günde 8 saat ve üzeri televizyon izleyenlerin oranı ise \%2 olarak ölçülmüştür.

Televizyon başında geçirilen süre ile ilgili olarak cinsiyetler arasında anlamlı bir farklılık bulunmamaktadır. Yaş aralıkları göz önüne alındığında televizyon karşısında en çok süre geçirenlerin 45 yaş üstü olduğu görülmektedir. En az televizyon izleyen grup ise 19-25 yaş aralığında olanlardır. Yaş ve cinsiyet birlikte ele alındığında ortaya şu sonuçlar çıkmıştır: Televizyon başında en az vakit geçirenler 19-25 yaş aralığındaki erkeklerdir, en çok televizyon izleyenlerse 45 yaş üstü kadinlardir.

Tablo-5: Evde Bulunan Televizyon Sayıs1

\begin{tabular}{lcc}
\hline Televizyon sayıs & Kişi sayıs & Yüzde \% \\
\hline 1 & 234 & 58,5 \\
2 & 128 & 32 \\
3 & 31 & 7,8 \\
$4+$ & 4 & 1 \\
Cevaps1z & 3 & 0,8 \\
\hline
\end{tabular}

29 Tablolarda yer alan küsuratlı rakamlar okumayı güçleştirmemek adına metin içinde aşağı ya da yukarı yuvarlanmıştır. Virgülden sonraki 5 ve diğer küsuratlar bir üst sayıya tamamlanmış, 5 ’ten küçük küsuratlar ise bir alt sayıya çekilmiştir.

30 Rakamların yuvarlanmasından dolayı bazı tablolardaki toplam oran 100'ün üzerinde çıkmaktadır. Ancak biz tablolarda tek bir rakam olarak oranı 100 şeklinde kullandık. 


\begin{tabular}{lll}
\hline Toplam & 400 & 100 \\
\hline
\end{tabular}

Modern dünyada evlerde televizyon sayısının arttığı düşüncesine istinaden deneklere evlerinde bulunan televizyon sayısı sorulmuş, \%99'unun evinde en az 1 televizyon bulunduğu tespit edilmiştir. Evinde televizyon bulunmayan 3 denek soruyu yanıtsız birakarak not düşmüștür. Evinde tek televizyona sahip olanlar (\%59) çoğunluktadır. Ancak evlerinde birden fazla televizyon bulunanların sayısı da yadsınamayacak orandadır. Buna göre deneklerin \%32'sinin evinde 2, \%8'inin evinde 3 televizyon bulunmaktadır. \%1'lik bir grup ise evinde 4 veya daha fazla televizyon bulunduğunu belirtmisstir.

Tablo-6: Televizyon İzleme Amacı

\begin{tabular}{lccc}
\hline Amaç & & Kişi sayıs & Yüzde \% \\
\hline $\begin{array}{l}\text { Serbest } \\
\text { dinlenme }\end{array}$ & haman & 260 & 65,0 \\
Haber alma ve bilgi edinme & & 95 & 23,8 \\
Yalnız hissetmeme & 28 & 7 \\
Diğer & 15 & 3,8 \\
Cevapsız & 2 & 0,5 \\
Toplam & $\mathbf{4 0 0}$ & $\mathbf{1 0 0}$
\end{tabular}

Deneklerin televizyon karşısında hangi amaçla vakit geçirdiğini ölçebilmek amacıyla sorduğumuz bu soruya verilen cevapların ilk sırasında \%65'lik oranla "serbest zaman harcama ve dinlenme" seçeneği yer almaktadır. "haber alma ve bilgi edinme" seçeneği \%24 ile onu takip etmektedir. "Yalnız hissetmeme" seçeneği ise \%7'lik oranla üçüncü sıradadır. Dolayısıyla büyük bir çoğunluk televizyonu serbest zaman harcama aracı olarak görmektedir.

Denekleri kendi içinde gruplandırdığımızda televizyonu daha çok (\%79) serbest zaman harcama ve dinlenme aracı olarak kullanan grubun ilk sırasında 12-18 yaş aralığındaki gençler bulunmaktadır. Televizyonu haber alma ve bilgi edinme aracı olarak görenlerin ilk sırasında ise 19-25 yaş arasındaki gençler (\%43) yer almaktadır. Televizyonu, yalnız hissetmeme aracı olarak değerlendirenler içinde 45 yaş üstü kadınlar \%40'la ilk sıradadır. Kadınların (\%71) televizyonu serbest zaman harcama ve dinlenme aracı olarak erkeklerden (\%59) daha fazla tercih ettiğini görmekteyiz. Erkeklerse (\%32) kadınlara oranla (\%16) televizyonu daha çok haber alma ve bilgi edinme aracı olarak kullanmaktadır. Yalnız hissetmemek için televizyon izleyen kadınlarla erkekler arasında belirgin bir fark ortaya çıkmamıştır.

Dağlı ve Hacıbektaşoğlu'nun çalışmasında televizyonun aile için sosyalleşme ve haber alma aracı olarak görüldüğü, ayrıca televizyon izlemenin bir serbest zaman aktivitesi olduğu belirtilmiştir. ${ }^{31} \mathrm{Bu}$ sonuç bizim çalışmamızda ortaya çıkan televizyonun serbest zaman harcama aracı olarak görülmesiyle benzerlik taşımaktadır.

Özel sektörün yayın hayatında yer almaya başlamasından bu yana izleyiciyi artırmak ve kanalda tutmak amacıyla başta diziler olmak üzere çeşitli show programları yayın hayatına girmiştir. Programların artması ile birlikte televizyon, eğlence gereksinimini karşılayan bir serbest zaman harcama aracına dönüşmüştür. ${ }^{32}$

Tablo-7: Dizi İzlemeye Başlamada Etkili Faktörler

\begin{tabular}{lcc}
\hline Diziye başlamada etkili faktörler & Kişi sayısı & Yüzde \% \\
\hline Senaryo & 189 & 47,3 \\
Oyuncular & 107 & 26,8 \\
Fragman & 49 & 12,3 \\
Dizi ad1 & 17 & 4,3 \\
Yönetmen & 9 & 2,3 \\
Yayınlandığı gün & 7 & 1,8 \\
Diğer & 21 & 5,3 \\
Cevapsız & 1 & 0,3 \\
Toplam & $\mathbf{4 0 0}$ & $\mathbf{1 0 0}$ \\
\hline Televizyon dizisi izlemeye & başlamada en etkili faktör \%47'lik oranla "senaryo"
\end{tabular}

\footnotetext{
31 Özgül Dağlı \& Elçin Hacıbektaşoğlu, "Televizyon Reklamlarının Çocuk-Aile İlişkisi ve Boş Zaman Kavramı Ekseninde Değerlendirilmesi”, Üsküdar Üniversitesi Sosyal Bilimler Dergisi, 2015 (1), s. 186.

32 Kamil Şahin, "Kültürel Yozlaşmaya Neden Olan Bir Unsur Olarak Televizyon", Kırıkkale Üniversitesi Sosyal Bilimler Dergisi, 2011 (1), s. 252; Aziz, s. 92.
} 
olmuştur. Onu \%27 ile "oyuncular", \%12 ile "fragman" takip etmiştir. Daha sonra sirasıly "dizi adı", "yönetmen” ve "yayınlandiğı gün” gibi seçenekler gelmektedir.

Diziye başlamada en çok oyuncuların etkili olduğu yaş aralığ1 12-18'dir (\%36). Senaryoyu önceleyenler 45 yaş üstü deneklerdir (\%58). Senaryoyu en az önemseyenlerse \%40’lık dilimle 12-18 yaş aralığındaki gençler olmuştur.

Tablo-8: Dizi İzlemeyi B1rakmada Etkili Faktörler

\begin{tabular}{lcc}
\hline Diziyi bırakmada etkili faktörler & Kişi sayıs & Yüzde \% \\
\hline Ahlakî değerlere uygunsuzluk & 135 & 33,8 \\
Aynı gün başka diziyi takip etme & 76 & 19 \\
Oyuncuların siyasî görüşleri & 45 & 11,3 \\
Gizli mesaj içeriyor olması & 34 & 8,5 \\
Oyuncuların özel hayatı & 7 & 1,8 \\
Diğer & 102 & 25,3 \\
Cevapsiz & 1 & 0,3 \\
Toplam & $\mathbf{4 0 0}$ & $\mathbf{1 0 0}$
\end{tabular}

Dizi izlemeyi bırakmada hangi faktörlerin etkili olduğunu araştırdığımız bu soruda deneklerin \%34'ü en önemli etkenin ahlakî değerlere uygunsuzluk olduğunu dile getirmiştir. İkinci sırada "diğer" seçeneği bulunmaktadır. Anketler incelendiğinde bu seçeneği işaretleyen deneklerin gerekçe olarak dizinin kalitesiz olmasını gösterdiği tespit edilmiştir. Üçüncü sırada bir başka dizinin takip ediliyor olması gelmektedir. Yani 5 denekten birinin (\%19) diziyi terk etmesinin sebebi bir başka dizidir. Oyuncuların siyasî görüşleri (\%11) de dizi izlemeyi bırakmanın sebepleri arasında gösterilmisstir. Bir diğer etken ise dizinin gizli mesaj (\%9) içeriyor olmasıdır. Bahsedilen oran çok yüksek olmasa da televizyon izleyicisi arasında bu anlamda bilinçli bir kesimin varlığından söz edilebilir.

Ahlakî değerlere uygun olmadığ1 için dizi izlemeyi terk edenlerin ilk sırasında 45 yaş üzerindeki denekler (\%56) yer almaktadır. 12-18 yaş aralığındaki gençler ise bu konuyu en az önemseyen grup (\%18) olarak karşımıza çıkmıştır. Aynı şekilde diğer yaş aralıklarına göre daha fazla tüketmeye meyilli olan 12-18 yaş aralığındaki gençler, bir başka dizi sebebiyle izlediği diziden en çok vazgeçenlerdir (\%32). Oyuncuların siyasi görüşüne göre dizi izlemeyi terk edenler daha çok 45 yaş üstü deneklerle (\%14) 19-25 yaş aralığındaki (\%13) gençlerdir. 19-25 ile 26-45 yaş aralığındaki denekler, dizinin gizli mesaj içeriyor olmasını olumsuz bir neden olarak görmektedir (her iki grupta da oran \%11'dir). Oyuncuların özel hayatını dikkate alanlar yalnızca 19-25 yaş aralığında olanlardır (\%5). Diğer yaş grupları bu konuyla ilgili herhangi bir beyanda bulunmamıştır.

Kadınlar (\%38), ahlakî değerlere uygun olmadığı için dizi izlemeyi erkeklerden (\%30) daha fazla terk etmektedir. Erkeklerin (\%16) herhangi bir diziyi kadınlara göre (\%7) daha fazla terk etme sebebi ise oyuncuların siyasî görüşüdür. Diğer seçenekler için erkeklerle kadınlar arasında birbirine yakın sonuçlar ortaya çıkmıştır.

ASAGEM'in 2010 yılında ortaya koyduğu Türkiye'de Aile Değerleri Araștırması'na göre, Türk toplumunda aile kurumu çok önemli bir yere sahiptir. Türk toplumu, evlilikte sadakatin önemli olduğunu ve eşlerin her türlü fedakarlığ1 yapması gerektiğini dile getirmiştir. Evlilik dışı cinsel ilişki kesinlikle kabul edilmemektedir. Aynı zamanda gayr-i meşru çocuk sahibi olmaya da karşı çıkılmaktadır. Evlenmeden aynı çatı altında yaşamak onaylanmamaktadır. Ailenin dini kurallara ve manevi değerlere bağlı kalması gerektiği düşünülmektedir. ${ }^{33}$ Ancak televizyonlarda yayınlanan dizilerin birçoğunun konusu itibariyle toplumun aile değerlerine ters düştüğü aşikardır. Son yıllarda Türk televizyon kanallarında yayınlanan dizilerin neredeyse tamamı yabancı dizilerin uyarlaması şeklindedir. Reytingleri oldukça yüksek olan İçerde, Anne, Hayat Şarkıs1, Paramparça ve No: 309 isimli diziler bunlara örnek verilebilir. ${ }^{34}$ Farklı bir toplumun ve kültürün etkisiyle üretilen bu diziler ne kadar uyarlanmaya çalışılsa da ahlakî değerlerimizle örtüşmemektedir. Bunun için No: 309 adlı diziye bakmak yeterlidir. Dizinin ana karakterleri Lale ve Onur birbirini hiç tanımayan kişilerdir, alkol alıp bir otelin 309 nolu odasında bir gece geçirirler. Ertesi gün hiçbir şey hatırlamazlar. Lale hamile kaldığını bir süre sonra öğrenir. Toplumumuzun ahlakî değerleriyle bağdaşmayan bu durum dizide sempatik gösterilmiştir. Öyle ki dizi, reyting rekorları kıran

\footnotetext{
33 Türkiye'de Aile Değerleri Araştırması, ASAGEM, Ankara 2010, ss. 302-304.

https: / / www.ntv.com.tr/galeri/yasam/avlu-hangi-dizinin-uyarlamasi-yabanci-dizi-ve-sinema-filmlerindenuyarlanan-diz,axJiP3CTUEi_N90635Tsug, Erişim Tarihi: 06.11.2018.
} 
romantik komedi kategorisinde yer almıştır.

Cinsellik ve şiddetle ilgili konular gençleri olumsuz etkilemekte, evliliğe bakış açılarını değiştirmekte ve evlilik dişı yaşam sürmeye özendirmektedir. ${ }^{35}$ Örneğin, Așk-1 Memnû̀ dizisi Türk aile yapısına ve manevi değerlere aykırı birçok durum taşımaktadır. Ancak televizyonun "değer" kaygisı bulunmamaktadır. ${ }^{36}$

Tablo-9: Takip ettiğim dizilerde kendimi/ailemi buluyorum.

\begin{tabular}{lcc}
\hline Dizide kendini/ailesini bulma & Kişi sayıs1 & Yüzde \% \\
\hline Evet & 49 & 12,2 \\
Hayır & 300 & 75 \\
Kararsiz & 51 & 12,8 \\
Toplam & $\mathbf{4 0 0}$ & $\mathbf{1 0 0}$ \\
\hline
\end{tabular}

Deneklerin \%12'si takip ettiği dizilerde kendisini ve ailesini yansıtacak özellikler bulduğunu söylerken \%75’i bunun aksini dile getirmektedir. \%13'lük bir grup ise kararsiz kalmıştır. Bu rakamlar dizilerde günümüz aile standartlarını baz almayan bir anlayışın var olduğunu göstermektedir. Diziler gerçek dünyadaki bireysel hayat ve aile yaşantısını yansıtmak yerine ulaşılamayacak özellikteki hayatları sunmaktadır. Dolayısıyla gerçek hayattaki bireyler dizilerde kendi yaşantılarından izler görememektedir.

Takip edilen dizilerde kendisini ve ailesini bulanların başında \%24'lük oranla 45 yaş üstü denekler gelmektedir. Kendisini ve ailesini bulamayanlar içindeyse \%86 ile 12-18 yaş arasındaki gençler ilk sıradadır. Bu rakamlar aslında gençlerin izlediği dizilerle 45 yaş üstü deneklerin izlediği dizilerin birbirinden farklı olduğunu ortaya koymaktadır. Kararsız olduğunu söyleyen denekler arasında \%19'luk oranla 19-25 yaş aralığındaki gençler öne çıkmıştır. Cinsiyetler arasında belirgin bir farklılık saptanmamıştır.

Türk televizyonlarında yayınlanan dizilerin çoğunlukla zengin kesimin hayatını konu edindiği görülmektedir. ${ }^{37}$ Lüks evlere ve eşyalara, son model arabalara, büyük bir şirkete sahip olma, dizilerde neredeyse olmazsa olmaz metalar haline gelmiştir. Dolayısıyla diziler kahir ekseriyetle geleneksel Türk aile hayatının genel karakteristiğini yansıtmamakta, kültürel yozlaşmaya neden olmaktadır.

Tablo-10: Kendimi oyuncularin yerine koyarak dizi izliyorum.

\begin{tabular}{|c|c|c|c|c|}
\hline $\begin{array}{l}\text { Kendini } \\
\text { koyma }\end{array}$ & oyuncularin & yerine & Kişi say1s1 & Yüzde \% \\
\hline Evet & & & 92 & 23 \\
\hline Hayır & & & 282 & 70,5 \\
\hline Kararsiz & & & 26 & 6,5 \\
\hline Toplam & & & 400 & 100 \\
\hline
\end{tabular}

Deneklerin \%23'ü kendisini oyuncuların yerine koyarak dizi izlediğini, \%71'i ise kendisini dizi kahramanlarından biriyle bağdaştırmadığını ifade etmektedir. \%7'lik bir denek grubu ise kararsız olduğunu belirtmiştir. Deneklerin çoğu dizileri dışarıdan bir göz olarak izlese de kendisini oyuncuların yerine koyup izleyenlerin sayısı azımsanmayacak düzeydedir. Bu bağlamda 45 yaş üstü kadınlar, \%48'lik oranla kendisini oyuncuların yerine koyarak dizi izlemede ilk sırada yer almıştır. $12-18$ ve 19-25 yaş arasındaki gençler de (her ikisi de \%24 orana sahip) hemen peşinden gelmektedir. Kendisini dizi karakterleriyle bağdaştırmamakta kararlı olan grup ise \%88'lik oranla 45 yaş üstü erkeklerdir. Konuya cinsiyetler açısından yaklaşıldığında kadınların (\%28) erkeklere göre (\%18) kendilerini daha çok oyuncuların yerine koyarak dizi izlediği ortaya çıkmıştır.

Aladağ’a göre izleyici, kendisini, takip ettiği dizilerdeki karakterlerin yerine koyarak hayatında canlandırmakta, hatta bu hayata özlem duymaktadır. Zira izleyiciler canlandırılan karakterle o kadar özdeşleşirler ki, bu rol hayatlarının bir parçası haline gelir ve yakın çevreleri tarafından o karakterin ismiyle bile çağrılabilirler. ${ }^{38}$

\footnotetext{
35 Türkiye'de Aile Değerleri Araștırması, s. 311.

36 Hüseyin Tuğrul Oktay, Televizyon Dizilerinin Toplumun Milli ve Manevi Değerleri Açısından Değerlendirilmesi; Așk-1 Memnu Dizisi Örneği, T.C. Radyo Televizyon Üst Kurulu, Uzmanlık Tezi, Ankara 2011, s. 143.

37 Şahin, s. 252

38 İdil Aladağ, Televizyon Dizilerinin Kültürel Yozlaşma Açısından İncelenmesi (Fırat Üniversitesi Öğrencileri Üzerine Bir Alan Araștırması), Fırat Üniversitesi Sosyal Bilimler Enstitüsü İletişim Bilimleri Anabilim Dall, Yayınlanmamış Yüksek Lisans Tezi, Elazığ 2012, s. 41.
} 
Televizyon simülasyon evrenine ait bir araçtır. ${ }^{39}$ Diziler de bu simülasyon evreninin bir parçasıdır. İzleyiciye gerçek olmayan görüntüleri gerçekmiş gibi hissettirir. Dizilerde rol alan insanlar ve hayvanlar, gerçek canlılar olduğu için dizi izlerken de bu gerçeklik noktasından hareket edilir. İzleyiciler yaşananların gerçek olduğu hissine kapılır. ${ }^{40}$ Araştırmamızdaki deneklerin 92'si (\%23) bu yanılsamayı yaşamaktadır. Toplum, zamanla, dizilerde olayların abartılarak yansıtılmasına alışmıştır. Dolayısıyla seyirci kendisini oyuncuların yerine koyarken bu abartılı durumu içinde yaşamakta, bu durumu gerçeklik zannetmektedir. Daha sonra gerçek hayatta yaşadığı olaylara, bunun abartılı halini içinde yaşadığı için, gerçeklik tepkisi verememektedir. Dizilerin olayları simüle edip gerçeklikten uzaklaştırma gibi olumsuz bir etkisi bulunmaktadır.

Tablo-11: Dizilerdeki aile hayatı benim aile hayatıma benziyor.

\begin{tabular}{lcc}
\hline Aile hayatının benzemesi & Kişi sayıs1 & Yüzde \% \\
\hline Evet & 29 & 7,2 \\
Hayır & 346 & 86,5 \\
Kararsiz & 25 & 6,3 \\
Toplam & $\mathbf{4 0 0}$ & $\mathbf{1 0 0}$ \\
\hline A
\end{tabular}

Anketimizin bu sorusuna deneklerin yalnızca \%7'si "evet" cevab1 verirken \%87 oranında "hayır" cevabı alınmıştır. Deneklerin \%6'sı ise "kararsız" olduğunu belirtmiştir.

Dizilerdeki aile hayatının kendi hayatına benzediğini dile getirenler arasında 45 yaş üstü kadınlar \%20 ile ilk sırada yer almıştır. Dizilerin kendi hayatını yansıtmadığını belirtenlerin ilk sırasında ise \%92 ile 12-18 yaş arasındaki gençler gelmektedir, onu \%91 oranıyla $26-45$ yaş aralığındaki denekler izlemektedir. Bu soruya verilen cevaplarda erkeklerle kadınlar arasında belirgin bir farklılık gözlenmemiştir.

Tablo-12: Dizilerdeki ev ve eşyaları beğeniyor, onlara sahip olmak istiyorum.

\begin{tabular}{lcc}
\hline Ev ve eşyaların beğenilmesi & Kişi sayıs1 & Yüzde \% \\
\hline Evet & 94 & 23,5 \\
Hayır & 248 & 62 \\
Kararsiz & 58 & 14,5 \\
Toplam & $\mathbf{4 0 0}$ & $\mathbf{1 0 0}$
\end{tabular}

Ankete katılanların \%24'ü dizlerdeki ev ve eşyaları beğendiğini, aynı zamanda onlara sahip olmak istediğini belirtmiş, \%62'si ise konuya olumsuz yaklaşmıștır. Deneklerin \%15’i kararsız olduğunu ifade etmiştir. "Evet" diyen 94 kişinin 61'i kadın, 33'ü erkektir. Şahin'in çalışmasında da televizyon dizilerinde gösterilen zenginler gibi bir hayata sahip olmak konusunda kadınların erkeklerden daha istekli olduğuna işaret edilmiştir. ${ }^{41}$ Diğer yaş gruplarına göre en az "evet" (\%16) ile en fazla "hayır" (\%80) cevab1 45 yaş üstü deneklerden gelmiştir.

Dizileri gözlemlediğimizde genel olarak karşımıza villa, yalı tarzında evler çıkmaktadır. Evlerin dekorasyonu ise lüks eşyalarla gerçekleştirilmiştir. Toplumun çok az bir kısmı bu imkanlara sahipken dizilerde ultra lüks hayatlar yaşanmaktadır. Çalıșmamızda deneklerin çoğu dizilerde kullanılan ev ve eşyalara sahip olma konusunda istekli değildir. Çünkü izleyiciler kullanılan ev ve eşyaların maliyetinin oldukça yüksek ve güç ulaşılabilir olduğunun farkındadir.

Tablo-13: Dizilerde kullanılan kıyafet ve takıları beğeniyor, onları satın almaya çalışıyorum.

\begin{tabular}{lcc}
\hline Kıyafet ve takıların beğenilmesi & Kişi sayısı & Yüzde \% \\
\hline Evet & 62 & 15,5 \\
Hayır & 298 & 74,5 \\
Kararsız & 29 & 7,2 \\
Cevapsiz & 11 & 2,8 \\
Toplam & $\mathbf{4 0 0}$ & $\mathbf{1 0 0}$ \\
\hline
\end{tabular}

Dizilerin tüketime etkisini ortaya koymak amaciyla oluşturduğumuz "Dizilerde kullanılan kıyafet ve takıları beğeniyor, onları satın almaya çalışıyorum.” önermesine

\footnotetext{
39 Jean Baudrillard, Simülarklar ve Simülasyon, Çeviri: Oğuz Adanır, Ankara 2011, s. 8.

40 https://www.academia.edu/7369795/Jean_Baudrillard_ve_Sim\%C3\%BClasyon_Kuram\%C4\%B1, Erişim Tarihi: 25.05.2017.

${ }^{41}$ Şahin, s. 266.
} 
deneklerin \%16’s1 "evet”, \%75’i "hayır” şeklinde cevap vermiştir. 29 denek de (\%7) kararsızdır. "Evet" cevabı verenler içinde 45 yaş üstü kadınların \%20'lik oranla ilk sırada geldiği görülmektedir. Bir diğer istatistik de dizilerde kullanılan kıyafet ve takıları beğenerek satın almaya çalışan kadın ve erkeklerin sayısı birbirine eşittir.

Bizim çalışmamızda yer alan deneklerin çoğunluğu dizilerdeki kıyafet veya takılarla ilgilenmemektedir. Ancak Tanrı̈̈ver çalışmasında bunun aksine dizilerin bireyi özendirdiği ve trendi belirlediği konusuna vurgu yapmıștır. Türkiye'de beğenilen dizi karakterlerinin kendi isimleriyle anılan ürünlerinin (Bihter çizmesi, Sıla tokası, Abiye Kuzu taytı) rağbet gördüğünden bahsetmiştir. Özellikle 2008 y1lında döneminin en çok izlenen dizilerinden biri olan Aşk-1 Memnû'da başrol oyuncusu olan Bihter karakterinin kullandığ ürünler popüler olmuş, mağaza ve semt pazarlarında "Bihter elbisesi", "Bihter yüzüğü" ve "Bihter parfümü" adıyla satışa çıkarılmıştır. ${ }^{42}$ Talep fazla olduğu için de oldukça yaygınlaşmıştır.

Yaprak Dökümü dizisinde Ferhunde'nin kullandığı, "Ferhunde bilekliği" birçok bijuteride satılmaktadır. Dizi takipçileri bu takıları satın alarak karakterlere benzemeye çalışmakta ve bu şekilde kendilerini iyi hissetmektedir. ${ }^{43}$

Günümüzde tüketim sektöründe ürünleri en fazla yer alan dizi Diriliş Ertuğrul'dur. Birçok yerde dizide kullanılan takılar Diriliş veya Ertuğrul yüzüğü, Kayı takıları adıyla pazarlanmaktadır. Aynı zamanda diziyle birlikte Kayı amblemi de popülarite kazanmıştır. Ancak çalışmamızın sonuçlarına göre katılımcılarımızın çoğu artık dizilerde kullanılan bu ürünleri satın alma eğiliminde değildir.

Geçtiğimiz yıllarda "Dizide gördüm, benim olsun!" başlı̆̆ıyla yayınlanan bir haberle dizilerde beğenilen ürünlerin nereden, ne kadara alındıklarını bildiren bir uygulamadan bahsedilmiştir. Telefonlara yüklenen bu uygulama sayesinde dizide görülüp beğenilen kıyafet, aksesuar, çanta ve ayakkabılara kolaylıkla ulaşılabilmektedir. Böyle bir uygulamanın varlığ da ürünleri takip eden ve satın almak isteyen bir kitlenin olduğunu göstermektedir. ${ }^{44}$

Tablo-14: Dizilerde kutlanan özel günler gerçek hayatta beklentimi artırıyor.

\begin{tabular}{lcc}
\hline Beklentinin artması & Kişi sayısı & Yüzde \% \\
\hline Evet & 141 & 35,2 \\
Hayır & 212 & 53 \\
Kararsiz & 44 & 11 \\
Cevapsiz & 3 & 0,8 \\
Toplam & $\mathbf{4 0 0}$ & $\mathbf{1 0 0}$
\end{tabular}

Deneklerin \%35’i dizilerde kutlanan özel günlerin gerçek hayatta beklentisini arttırdığını dile getirirken \%53'ü böyle bir beklenti içinde bulunmadığını beyan etmiştir. $\% 11^{\prime}$ lik bir denek grubu kararsız kalmıştır. Kadınların beklentisi (\%46), erkeklerden $(\% 25)$ daha fazladır. Beklentiyi en yüksek tutan grup 19-25 yaş arasındaki gençlerdir (\%41). Aynı şekilde konu cinsiyet açısından irdelendiğinde de 19-25 yaş aralığındaki kadın deneklerin (\%51) en yüksek beklentiye sahip olduğu ortaya çıkmıştır.

Sevgililer günü, evlilik yıl dönümü gibi özel günlerde eşler tarafından beklentinin karşılanmaması durumunda ilişkiler bozulabilir. Bunun nedeni medyanın davranışlara yön vericiliğidir. Aynı şekilde anneler günü, babalar günü gibi özel günlerde de medya beklentiyi artırmaktadır. ${ }^{45}$ Özellikle romantik dizilerde sevgililer günü, aile dizilerinde anneler günü, babalar günü her yıl mutlaka işlenen temalar arasindadır.

Tablo-15: Gerçek hayatta beğendiğim dizi oyuncusu gibi davranabiliyor ya da konuşabiliyorum.

\begin{tabular}{lcc}
\hline Dizi oyuncusu gibi davranabilme & Kiși sayıs1 & Yüzde \% \\
\hline Evet & 39 & 9,8 \\
Hayır & 328 & 82 \\
Karars1z & 33 & 8,3 \\
Toplam & $\mathbf{4 0 0}$ & $\mathbf{1 0 0}$
\end{tabular}

Dizi karakterlerinin ne ölçüde rol model alındığını tespit etmek üzere hazırladığımız

\footnotetext{
42 Tanriöver, s. 182.

43 Serpil Tepecik, Popüler Kültür Unsurlarından Olan Televizyon Dizlerindeki Aile Kurgusu, Dumlupınar Üniversitesi Sosyal Bilimler Enstitüsü Sosyoloji Anabilim Dalı, Yayınlanmamış Yüksek Lisans Tezi, Kütahya 2010, s. 74 .

44 http://www.milliyet.com.tr/dizide-gordum-benim-olsun-/cumartesi/haberdetay/09.03.2013/1678008/ default.htm, Erişim Tarihi: 03.09.2018.
}

45 Özdemir, s. 30 
"Gerçek hayatta beğendiğim dizi oyuncusu gibi davranabiliyor ya da konuşabiliyorum." önermesine "evet" şeklinde cevap verenlerin oranı \%10'dur. Büyük çoğunluk (\%82) ise dizi oyuncuları gibi davranamadığını ifade etmiștir. Deneklerin \%8'i de kararsızdır.

Dizi oyuncusu gibi davranabildiğini ya da konuşabildiğini söyleyen denekler arasında 19-25 yaş arasındaki erkekler \%17'lik oranla ilk sırada gelmekte, onları \%16 ile 12-18 yaş arasındaki erkekler izlemektedir. Cinsiyet bağlamında da erkeklerin oranı (\%12) kadınlardan (\%8) daha yüksektir.

Oran çok yüksek olmasa da dizi karakterlerini taklit eden bir kitle bulunmaktadır. Dizilerin çoğu izleyici üzerinde birtakım imgeler bırakmaktadır. Dizi karakterlerinin jest ve mimikleri, konuşma tarzı, giyim-kuşamı, saç şekli gibi özellikleri izleyiciyi etkileyebilmektedir. Ancak Konukman'a göre bunu gündelik yaşamda kullanan kişi sayısı azdır. Bizim çalışmamızda da dizi karakterlerini taklit eden kişi sayısı çok değildir. Konukman çalışmasını 2006 yılında tamamlamış ve dönemin dizilerinden Kurtlar Vadisi, Ekmek Teknesi, Avrupa Yakası'nı ele almıştır. Kurtlar Vadisi'nde ana karakter Polat Alemdar izleyiciyle özdeşleşmiş ve o dönemde taklit edilmiştir. Ekmek Teknesi'nde Heredot Cevdet karakterinin konuşma biçimi izleyici tarafından benimsenmiştir. Avrupa Yakası'nda Selin karakterinin "Oha falan oldum yani." repliği gençler arasında oldukça yaygın hale gelmiştir. ${ }^{46}$ Yine geçmiş dönem dizilerinden Yahşi Cazibe'de Simge karakterinin "Çok mağdurum." sözü gençler tarafından benimsenmiş ve sıkça kullanılmıştır. Leyla ile Mecnun dizisinde Mecnun karakterinin soru ekleri de (Hangi mi hastahane?) sevenleri tarafından hala kullanılmaktadır. Günümüzün popüler dizilerinden biri olan İçerde'de Coşkun karakterinin yüzüğüyle çıkarttığı "tak tak taka tak" sesi izleyici tarafından imgesel anlamda benimsenmiştir. Bu ses diziyi takip edenler arasında bir şifre haline gelmiş ve mesaj sesi olarak da kullanılmıştır. Aynı şekilde Payitaht Abdülhamid'de de bu anlamda öne çıkan karakterler mevcuttur. Fuat Efendi karakterinin "dîîi mi, dî mi dî mi" repliği ile Halil Halit Bey'in pek çok şeye tahammülünün olmaması bu bağlamda ele alınabilir.

Günümüze kıyasla geçmiş dönemlerde dizi karakterlerinin daha fazla taklit edildiği görülmektedir. Bunun nedeni bugün artık dizi karakterlerinin yerini internet fenomenlerinin almış olmasıdır. Gençler arasında hala popüler kissilikler taklit edilmektedir. Ancak rakam \%10 civarındadır ve bu grup 12-25 yaş arasındaki gençlerden (\%90) oluşmaktadır.

Tablo-16: Dizi izlerken ailemle yeterli iletişim kuramiyorum.

\begin{tabular}{lcc}
\hline Aile ile iletişim kuramama & Kişi sayısı & Yüzde \% \\
\hline Evet & 153 & 38,3 \\
Hayır & 208 & 52 \\
Kararsiz & 37 & 9,3 \\
Cevapsiz & 2 & 0,5 \\
Toplam & $\mathbf{4 0 0}$ & $\mathbf{1 0 0}$ \\
\hline
\end{tabular}

Dizi izlerken ailesiyle yeterli iletişim kuramadığını söyleyen deneklerin oranı \%38 olarak ölçülmüştür. \%52'lik bir grup bu önermeye "hayır" şeklinde yanıt vermiştir. Kararsızların oranı ise \%9'dur. Ailesiyle yeterli iletișim kuramadığını dile getiren kadınlar $(\% 44)$ erkeklerden (\%33) daha fazladır. Bu konuyu kendisine en fazla dert edinen grup 45 yaş üstü (\%48) deneklerdir. Özellikle 45 yaş üstü kadınların \%60'lı oranla ilk sırada yer aldığ görülmüştür. Onları 19-25 yaş aralığındaki kadınlar (\%49) takip etmektedir. Hem dizi izleyip hem de aileleriyle en güçlü iletişimi gerçekleştirenler (\%59) 12-18 yaş aralığındaki gençlerdir.

Elde edilen rakamlara göre deneklerin yarısından fazlası dizilerin aile içi iletişimi etkilemediğini söylemiştir. Aziz'in Radyo ve Televizyona Giriş isimli çalışmasında televizyon, eski Türk evlerinde aileyi bir araya getiren mangala benzetilmiştir. ${ }^{47}$ Eski Türk evlerinde aile mangal yapma aktivitesiyle bir araya gelirken günümüzde dizi saatlerinde televizyonun karşısında buluşmaktadır. Ancak artık eski Türk ailelerinde olduğu gibi bir sohbet havası yoktur. Zira televizyon monolog konuşma diline sahiptir, bu nedenle zaman zaman aileyi bir araya getirici etkisi olmasına rağmen bizim çalışmamızda da ortaya çıktığı üzere dizi izleyenlerin önemli bir bölümü aileleriyle yeterli iletişim kuramamaktadır.

Aslında dizi izlerken başka işlerle uğraşmaktan hoşlanmayan deneklerin \%48'lik bir dilime sahip olduğu göz önünde bulundurulursa ailesiyle yeterli iletişim kuramayanların

\footnotetext{
46 Emrah Alparslan Konukman, Medya ve Kültür: Son Dönem Televizyon Dizilerinin Yaşam Tarzı Üzerindeki İmgeleri, Gazi Üniversitesi Sosyal Bilimler Enstitüsü Gazetecilik Anabilim Dalı, Yayınlanmamış Yüksek Lisans Tezi, 2006 , s. 87.

47 Aziz, s. 91.
} 
oranının daha yüksek olduğu da söylenebilir. Denekler açık uçlu soruları cevaplandırırken zihinlerini meşgul eden işlerden kaçındıklarını, ancak meyve yemek, çay içmek gibi aktivitelerde bulunduklarını belirtmişlerdir. Bu sonuç Türk toplumunun dizi izleme ritüellerinin olduğunu ortaya koymaktadır. Tanrı̈ver’in çalışmasında da benzer şekilde dizi izleme ritüelleri içerisinde yapılan tek işin bir şeyler yemek ve içmek olduğu saptanmıştır. ${ }^{48}$ Başka işlerle uğraşmaktan hoşlanmayan izleyici kitlesi akşam ailesiyle daha kaliteli geçirebileceği zamandan çalmış ve tek taraflı iletişimi seçmiştir. Bu durum aile bağlarının yipranmasina neden olmaktadir.

Tablo-17: Evimizde televizyon kumandası kavgası yaşıyoruz.

\begin{tabular}{lcc}
\hline Televizyon kumandası kavgası & Kişi sayısı & Yüzde \% \\
\hline Evet & 114 & 28,5 \\
Hayır & 267 & 66,8 \\
Kararsiz & 18 & 4,5 \\
Cevapsiz & 1 & 0,3 \\
Toplam & $\mathbf{4 0 0}$ & $\mathbf{1 0 0}$ \\
\hline
\end{tabular}

Deneklerin \%29'u evinde televizyon kumandası kavgası yaşandığını doğrularken \%67'si böyle bir anlaşmazlık gerçekleşmediğini söylemektedir. Problemin varlığı daha çok 45 yaş üstü denekler (\%58) tarafından dile getirilmiştir. Elde ettiğimiz cevaplar cinsiyet açısından belirgin bir farklılık taşımamaktadır.

Türk ailesinde televizyon kumandasına sahip olmak oldukça önemlidir. Genel olarak evin hakimiyeti kimdeyse kumanda da onda bulunur. Ataerkil bir toplum oluşumuz hasebiyle bu hak daha çok babanındır. İşten eve gelen baba, televizyonu daha çok serbest zaman harcama ve dinlenme aracı olarak kullanmaktadır. Bu saatler aynı zamanda dizilerin de yoğun olarak yayınlandığı zaman dilimidir. Kumandayı elinde bulunduranla diğer aile fertlerinin farklı türde programlar izlemek istemesi halinde evde televizyon kumandası önemli bir sorun haline gelmektedir. Kumanda kavgaları genelde bir diziye bağımlı hale gelmekten kaynaklanmaktadır. Uzun süre diziyi takip eden izleyici, saati geldiğinde dizisi açılmadığında huzursuzlanmakta ve kumandaya sahip olmak istemektedir. Bizim çalışmamızda yer alanlardan 114'ünün bu durumu yaşadığı saptanmıştır. Deneklerin pek çoğunun (267 kişi) bunu bir sorun olarak görmemesi ise değișen sosyal ve ekonomik şartlar neticesinde evlerde birden fazla televizyon bulunması ile ilişkili olabilir. Nitekim Tablo-5’te gösterdiğimiz gibi katılımciların \%40'inın evinde birden fazla televizyon mevcuttur. Bu kesimin evde kumanda kavgası yaşama ihtimali düşüktür.

"Kumanda bende olmadiğı zaman huzursuzluk hissediyorum." önermemize 101 kiși "evet" şeklinde cevap vermiştir. Bu iki önermeyi birlikte incelediğimizde "evet" yanıtlarının birbirine oldukça yakın olduğunu görürüz. Dolayısıyla kumandanın kendisinde olmadığ durumlarda huzursuzluk yaşayan birey evde kumanda tartışması yaşamaktadır. Bir başka ifadeyle evde kumanda kavgası yaşandığını söyleyen deneklerin tamamı kumandaya sahip olamayanlardir.

Tablo-18: Takip ettiğim dizinin varsa romanını okumayı isterim.

\begin{tabular}{lcc}
\hline Dizinin romanını okuma & Kissi say1s1 & Yüzde $\%$ \\
\hline Evet & 127 & 31,8 \\
Hayir & 223 & 55,8 \\
Kararsiz & 49 & 12,3 \\
Cevapsiz & 1 & 0,3 \\
Toplam & $\mathbf{4 0 0}$ & $\mathbf{1 0 0}$ \\
\hline
\end{tabular}

Deneklerin \%32'si takip ettiği dizinin varsa romanını okumayı arzuladığını ifade ederken yarısından fazlası (\%56) böyle bir istekte bulunmadığını belirtmiştir. Kitap okuma isteği konusunda öne çıkan denekler 12-18 ile 19-25 yaş arasındaki gençlerdir (Her iki grupta da "evet" cevabı \%37 olarak ölçülmüştür.) Okumayacağını beyan edenler arasında ise 45 yaş üstü denekler \%86 ile ilk sırada yer almıştır. Konuya cinsiyet açısında yaklaşıldığında 12-18 yaş aralığındaki kadınların \%50'lik oranla okumaya en hevesli grup olduğu ortaya çıkmaktadır. Onları takip edenler ise \%41 ile 19-25 yaş aralığındaki erkeklerdir.

Toplum içerisinde "Okumadım, ama dizisini, filmini seyrettim." diyen bir kesim vardır. Çünkü izlemek okumaktan daha zahmetsiz görülmekte ve diziler bu hazırcılığı topluma

48 Tanriöver, s. 172. 
empoze etmektedir. Okumaktan çok izlemeyi tercih eden toplum, diziler sayesinde tembelleştirilmektedir. Cemil Meriç, genel olarak televizyondan şu şekilde bahsetmiştir: " $O$, şuuru iğdiş edilmiş, hiçbir zaman okumak ve düşünmek alışkanlığı kazanmamış sokaktaki adam için icat edilmiş bir nevi afyondur."49 Bizim çalışmamızda da ortaya çıktığı üzere, kararsızlarla birlikte düşünüldüguünde, deneklerin \%68'i aynı hikâyenin kitabını okumayı değil de Meriç’in ifadesiyle, onu adeta bir afyon gibi, düşünmekten alıkoyacak, dizileştirilmiş halini tercih etmektedir.

Tablo-19: Reklam girdiğinde kanalı değiștiririm.

\begin{tabular}{lcc}
\hline Reklamda kanal değiştirme & Kişi sayısı & Yüzde \% \\
\hline Evet & 316 & 79 \\
Hayir & 71 & 17,8 \\
Kararsiz & 13 & 3,3 \\
Toplam & $\mathbf{4 0 0}$ & $\mathbf{1 0 0}$ \\
\hline
\end{tabular}

Deneklerin büyük çoğunluğu (\%79) reklamlar başladığında kanal değiştirme eğilimindedir. Reklam başladığında izlemenin gereksiz olduğunu, reklam arasında başka bir diziyi açıp izlediğini belirtenler olmuştur. Bazıları da reklamların açık kaldığını, ancak evde kimsenin seyretmediğini söylemiştir. Reklamlar her ne kadar seyredilmiyor olsa da açık kaldığı sürece subliminal anlamda çocukların zihinsel ve psikolojik gelişimini etkilemektedir. Reklamların çoğunlukla hedef aldığı tüketici kitle çocuklardır. Sloganlaştırdığı reklam mesajları ve müzikleri ile çocukların dikkatini çekmektedir. Böylece çocukların yiyecek ve giyecek tercihlerini doğrudan şekillendirir.50 Ebeveynler evde reklamları kimsenin izlemediğini düşünseler de çocuklar bu sloganlaştırılmış dilden oldukça etkilenir. Yoğun imge ve sesler çocuğun kişisel gelişimini olumsuz etkilemektedir.

Tablo-20: Reklamlar ihtiyaç duymadığım ürünler almama yol açıyor.

\begin{tabular}{lcc}
\hline Reklamların alışverişe etkisi & Kişi sayıs & Yüzde $\%$ \\
\hline Evet & 81 & 20,3 \\
Hayır & 289 & 72,3 \\
Kararsiz & 30 & 7,5 \\
Toplam & $\mathbf{4 0 0}$ & $\mathbf{1 0 0}$
\end{tabular}

Deneklerin \%20'si reklamların ihtiyaç duyulmayan ürünlerin satın alınmasını tetiklediğini dile getirirken \%72'si böyle bir etkisinin olmadığını düşünmektedir. Kararsızların oranı \%8'dir. Bizim çalışmamızda, reklamların erkekleri (\%22) kadınlardan (\%19) daha fazla etkilediği tespit edilmisstir. Bunun dışındaki sınıflandırmalarda belirgin bir farklılık ölçülmemiştir.

Televizyon dizilerinde yaratılan karakterler tüketim kültürünü doğrudan etkilemektedir. Özellikle popüler dizilerdeki ana karakterlerin toplumda kabul görmesi onun tüketim alışkanlıklarının da kolayca kabul edilmesini sağlamaktadır. ${ }^{51}$ Bu nedenle dizilerde bolca reklama yer verilir. Klasik reklam yayını, dizide ürün yerleştirme, sanal reklamlar, bant reklam şeklinde birçok reklam çeșidi vardır. Dizideki karakterlerin kıyafetleri ve bulundukları mekândaki eşyalar üretici firma tarafindan diziye reklam olarak yerleștirilmiștir. ${ }^{52} \mathrm{Bu}$ durumda birey, televizyon karşısında hem izleyici hem de tüketici konumunda bulunmaktadir.

Ürün yerleştirme görsel ve sözel şekilde gerçekleşebilir. Görsel ürün yerleştirme stratejisinde sözlü mesaj içermeden izleyiciye markayla ilgili mesajlar gönderilir. Bu durumda marka ya da logo doğal ortamda görüntülenebilmektedir. Dizide kullanılan telefonun veya arabanın markasının açık bir şekilde görüntülenmesi buna örnek verilebilir. Sözel ürün yerleştirme ise görsellik olmaksızın sadece sözle izleyicinin zihnine gönderilen mesajları kapsamaktadır. ${ }^{53}$ Türk dizilerinde daha çok görsel ürün yerleştirme kullanılmaktadır.

Daha önce irdelediğimiz gibi tüketiciler dizilerde kullanılan kıyafet ve eşyaları satın alma eğilimi gösterebilir. Ancak bu soruya verilen yanıtlara göre deneklerin büyük çoğunluğu ihtiyaç duymadığı ürünü reklam vasıtasıyla almadığını ifade etmiştir.

\footnotetext{
${ }^{49}$ Cemil Meriç, Kültürden İrfana, İstanbul 1986, s. 404.

50 Dağlı \& Hacıbektaşoğlu, s. 190.

51 Özlem Kükrer Aydın, “Televizyon Reklamlarında Dizi Karakteri Kullanımıyla Sunulan Tüketim Kültürü Değerleri: Yalan Dünya Örneği’, Journal of Yasar University, 2014, 9 (36), s. 6276.

52 Tanriöver, s. 78.

53 Emet Gürel \& Jale Alem, “Kurgusal Ürün Yerleştirme”, Gazi Üniversitesi İletişim Fakültesi Dergisi, 2005 (20), s. 137.
} 


\section{Sonuç}

Uzun yıllardan beri evlerin başköşesine oturan hatta odaların nasıl dizayn edileceğini dahi belirleyen televizyon, önemli bir kitle iletişim aracıdır. Toplumsal anlamda birtakım işlevlere sahiptir. Akla ilk olarak televizyonun haber ve bilgi aktarma fonksiyonları gelmektedir. Ancak bizim araştırmamızda elde edilen bulgulara göre ilk sırada televizyon izlemenin bir serbest zaman harcaması ve dinlenme aktivitesi olarak görüldüğü ortaya çıkmıştır. Haber ve bilgi edinme işlevi ikinci sırada yer almıştır.

Televizyon Dizilerinin Toplum Üzerindeki Etkileri'ni ölçtüğümüz bu çalışma, basit tesadüfî örneklem tekniğiyle 200'ü erkek, 200'ü kadın olmak üzere Karabük halkından seçilen toplam 400 denekle gerçekleştirilmiştir. Deneklerin 100'ü 12-18, 150'si 19-25, 100'ü de 26-45 yaş aralığındaki bireylerden oluşmaktadır. 50'si ise kayıtlara 45 yaş üstü olarak geçmiştir. Deneklerin yaklaşık yarısı (\%49) üniversite öğrencisi ya da mezunudur. \%48’i günde en az 2 saatini televizyon karşısında tüketmektedir.

Ülkemizin sahip olduğu hayat standartları gereği akşam işten evine gelen birey, eğlence mekanlarına gidip para harcamak yerine serbest zamanını televizyon karşısında tüketmektedir. Kanalların artmasıyla birlikte her kesime hitap eden farklı türde programlar yayınlanmaya başlamıştır. Bu anlamda televizyon bireyi evine hapsedip toplumdan uzaklaştırmaktadır. Ülkemizde dizilerin yayınlanma süresi yaklaşık 2 saattir. Birbirini takip eden olay örgülerinden oluşan diziler izleyiciyi 2 saat boyunca televizyon karş1sinda tutar. Dolayısıyla bu süre toplumu gerçek yaşamdan alıkoymaktadır.

Evde birden fazla televizyon olması aile içindeki eksik iletişimi gündeme getirmektedir. Bizim çalışmamızda yer alan deneklerin \%41'inin evinde en az 2 televizyon bulunmaktadır. Televizyon sebebiyle iletişimin zaten zor olduğu hanede, birden fazla televizyonla ilişkiler bir kez daha bölünmüştür. Evin içinde televizyonlarla birlikte özel alanlar oluşturulmuş, herkes kendi özel alanı içerisinde monolog bir tarza sahip olan televizyonu seyretmeye koyulmuştur. Tek televizyon bulunan evlerde aile üyelerinin dizi saatinde odada buluşması televizyonun birleştirici bir etkisinin olduğunu gösterebilir. Ancak bu durumda bireyler birbirleriyle değil, televizyon ile etkileşim halindedir. Dolayısıyla televizyon aynı odada bulunmaya sevk etse dahi aileyi birleştirici bir etki gösterememektedir. Ayrıca deneklerin önemli bir k1sm1 (\%29) evlerinde televizyon kumandası kavgası yaşandığını da dile getirmiştir.

Televizyon dizisi izlemeye başlamada en etkili faktör \%47'lik oranla "senaryo" iken 1218 yaş aralığındaki gençler için \%36 ile oyuncular olmuştur. Dizi izlemeyi bırakmanın da birtakım sebepleri bulunmaktadır. Bu konuyla ilgili olarak "Ahlakî değerlere uygunsuzluk" maddesi en yüksek orana (\%34) sahip olmuştur. 12-18 yaş aralığındaki gençler ise bu konuyu en az önemseyen grup konumundadır (\%18). Ayrıca kadınların (\%38), ahlakî değerlere uygun olmadığı için dizi izlemeyi erkeklerden (\%30) daha fazla terk ettiği de elde edilen sonuçlardan biridir.

Çalışmamızda yer alan deneklerin yalnızca \%12'sinin takip edilen dizilerde kendisini ya da ailesini bulduğu dikkate alınırsa televizyonlarda yayınlanan dizilerin genel olarak Türk aile yapısını yansıtmadığı kanaatine rahatlıkla varılabilir. Buna rağmen deneklerin \%23'ü kendisini oyuncuların yerine koyarak dizi izlemektedir. Bu iki rakam (\%12; \%23) arasında bu kadar fark bulunması özellikle kadınların dizilerde gösterilen yaşantıya özenti duyması şeklinde izah edilebilir. Kadınlar yanılsamayı erkeklerden daha yoğun yaşamaktadır. Çalışmamızda televizyon dizilerinin toplumu özendirici birtakım etkilerinin olduğu saptanmıştır. Hemen her dizide bir holding sahibi, yalıda oturan zengin bir iş adamı konu edilmektedir. Diğer taraftan dizide, diziyi izleyen kitlenin yaşam şartları aşağılanmaktadır. Dolayısıyla izleyiciler, olması gerekeni lüks yaşam şartları olarak algılamakta, kendisini yoksun hissetmektedir. Aynı şekilde kadınların \%31'i dizilerdeki ev ve eşyaları beğendiğini, onlara sahip olmak istediğini belirtmiştir. Dizilerde kutlanan özel günler de kadınların gerçek hayattaki beklentisini arttırmaktadir.

Televizyon dizilerinde yansitılan olaylar kurmaca ve abartılıdır. Toplumun belli bir kısmı bu olayları gerçekmiş ve kendi yaşıyormuş gibi seyretmektedir. Kendisini oyuncuların yerine koyarak hem oradaki hayata özenmekte hem de olaylarla arasında bir bağlamsallık inşa etmektedir. Dizilerde görülen savaş ya da öldürme sahneleri bir simülasyon olarak izlendiğinde gerçeklik algısı yaratmakta, insanlar gerçek hayatta aynı şeyle karşılaştığında tepkisiz kalmaktadır. Zira dizilerde sürekli izlenen sahnelerle gerçeklik arasındaki fark artık ayırt edilemez hale gelmiştir. Aynı şekilde, her ne kadar Türk toplum yapısına uygun olmasa bile, dizilerde sergilenen erkek kadın ilişkileri artık toplum içinde de sıkça sahnelenmekte, normal ve kabul edilebilir görülmektedir. Diziler bu bakımdan toplumun yaşam tarzını, 
kültürünü, düşünce sistemini etkileyen programların başında gelmektedir.

Televizyon dizilerinin olumsuz etkilerinden biri de toplumu tembelleştirmesidir. Dizi saatinde yapılacak birçok iş varken dizi bağımlıları bu işleri ertelemekten kaçınmaz. Dizilerin varsa kitabını okumayı tercih edenlerin sayısı diğerlerine nazaran azdır. Çünkü dizi izlemek daha zahmetsizdir. Dizilerin kitaplardan daha kolay ulaşılabilir olduğu düşünülmektedir. Toplum bu şekilde önüne sunulanı hiç çaba göstermeden tüketmeye alışmakta, dolayısıyla diziler toplumu tembelleşmeye itmektedir.

\section{Kaynaklar}

Aladağ, İ. (2012). Televizyon Dizilerinin Kültürel Yozlaşma Açısından İncelenmesi (Fırat Üniversitesi Öğrencileri Üzerine Bir Alan Araştırması), Fırat Üniversitesi Sosyal Bilimler Enstitüsü İletişim Bilimleri Anabilim Dalı, Yayınlanmamış Yüksek Lisans Tezi.

Aydın, Ö. K. (2014). Televizyon Reklamlarında Dizi Karakteri Kullanımıla Sunulan Tüketim Kültürü Değerleri: Yalan Dünya Örneği. Journal of Yasar University, 9 (36), ss. 6261638.

Aziz, A. (1981). Radyo ve Televizyona Giriş. Ankara: Ankara Üniversitesi Siyasal Bilgiler Fakültesi Yayınları.

Büyükbaykal, C. I. (2005). Kitle İletişim Araçları ve Toplumsal Yaşam. İstanbul Üniversitesi Iletişim Fakültesi Dergisi, (21), ss. 71-75.

Baudrillard, J. (2011). Simülarklar ve Simülasyon. Çeviri: Oğuz Adanır, Ankara: Doğu-Batı Yayınları.

Baudrillard, J. (2004). Tüketim Toplumu. Çeviren: Hazar Deliçaylı \& Ferda Keskin, İstanbul: Ayrintı Yayınları.

Crowley, D. \& Heyer, P. (2014). İetişim Tarihi. Çeviren: Berkay Ersöz, Ankara: Siyasal Kitabevi.

Çakır, V. \& Kınıt, E. (2009). Televizyon Dizilerinde Ürün Yerleştirme ve Sponsorluğun Sonuçları. Global Media Journal Turkısh Edition, (5), ss. 19-47.

Dağlı, Ö. \& Hacıbektaşoğlu, E. (2015). Televizyon Reklamlarının Çocuk-Aile İlişkisi ve Boş Zaman Kavramı Ekseninde Değerlendirilmesi. Üsküdar Üniversitesi Sosyal Bilimler Dergisi, (1), ss. 183-212.

Ertunç, F. (2001). Çocuk Dünyasında Reklamın Rolü: Televizyon Reklamlarında Çocuklara Yönelik Düzenlemeler, T.C. Radyo ve Televizyon Üst Kurulu Uzmanlık Tezi.

Fichter, J. (2001). Sosyoloji Nedir?. Çeviren: Nilgün Çelebi, Ankara: Atilla Kitabevi.

Girgin, A. (2002). Uluslararası İletişim. İstanbul: Der Yayınları.

Gürel E. \& Alem J. (2005). "Kurgusal Ürün Yerleştirme", Gazi Üniversitesi İletişim Fakültesi Dergisi, (20), ss. 133-155.

Hasekioğlu, S. (2008). Reklam ve İdeoloji: Yazll Basında Yer Alan Reklamlara Göstergebilimsel Bir İnceleme. Ankara Üniversitesi Sosyal Bilimler Enstitüsü Gazetecilik Anabilim Dalı, Yayınlanmamış Yüksek Lisans Tezi.

Karaboğa, T. (2007). Bir Kitle İletişimsizlik Aracı Olarak Televizyon. Sosyoloji Notları Dergisi, (3), ss. 25-35.

Keskin, M. (2015). Görsel Medya ve Kamuoyu İişkisi: Televizyonda Siyasi Tartışma Programlarinın Söylem Analizleri. Maltepe Üniversitesi Sosyal Bilimler Enstitüsü Sosyoloji Ana Bilim Dalı, Yayınlanmamış Yüksek Lisans Tezi.

Konukman, E. A. (2006). Medya ve Kültür: Son Dönem Televizyon Dizilerinin Yaşam Tarzı Üzerindeki İmgeleri. Gazi Üniversitesi Sosyal Bilimler Enstitüsü Gazetecilik Anabilim Dalı, Yayınlanmamış Yüksek Lisans Tezi.

Kuyucu, M. (2015). Türkiye'de Tematik Tv Yayıncılığı: Gençlerin Tematik Televizyon İzleme Alışanlıklarının Televizyon Yayıncılığına Olan Yansımaları. International Journal of Social Science, (3), ss. 249-265.

Kuzu, A. \& Özveren, H. (2011). Tüketilen Tüketici, Sakarya Üniversitesi Fen Edebiyat Fakültesi Dergisi, (1), ss. 61-72.

Meriç, C. (1986). Kültürden İrfana. İstanbul: İnsan Yayınları.

Oktay, A. (1995). Medya ve Hedonizm. İstanbul: Yön Yayınları.

Oktay, H. T. (2011). Televizyon Dizilerinin Toplumun Milli ve Manevi Değerleri Açısından Değerlendirilmesi; Aşk-ı Memnu Dizisi Örneği, T.C. Radyo Televizyon Üst Kurulu, 
Uzmanlik Tezi, Ankara 2011.

Oskay, Ü. (1971). Toplumsal Gelişmede Radyo ve Televizyon. Ankara: Sevinç Matbaası.

Özdemir, M. (2009). İlköğretim Öğretmenlerinin Aile Değerleri ve Medyanın Aile Değerlerine Etkisi Hakkındaki Görüşleri, Yeditepe Üniversitesi Sosyal Bilimler Enstitüsü Eğitim Yönetimi ve Denetimi Ana Bilim Dalı, Yayınlanmamış Yüksek Lisans Tezi.

Sayılgan, E. (2014). Medya Sektöründe Bir Uzmanlaşma Olgusu Olarak Tematik Kanallar ve İzleyici Çeşitliliğinin Tematik Kanal Oluşumundaki Rolü. Gümüşhane Üniversitesi Iletişim Fakültesi E-Dergisi, (3), ss. 2-15.

Şahin, K. (2011). Kültürel Yozlaşmaya Neden Olan Bir Unsur Olarak Televizyon. Kırıkkale Üniversitesi Sosyal Bilimler Dergisi, (1), ss. 243-277.

Tanriöver, H. U. (2011). Türkiye'de Film Endüstrisinin Konumu ve Hedefleri. İstanbul: İstanbul Ticaret Odası Yayınları.

Tanrı̈̈ver, H. U. (2012). Türkiye'de Televizyon Yayıncılığı 2011. İstanbul: İstanbul Ticaret Odası Yayınları.

Tepecik, S. (2010). Popüler Kültür Unsurlarından Olan Televizyon Dizlerindeki Aile Kurgusu, Dumlupınar Üniversitesi Sosyal Bilimler Enstitüsü Sosyoloji Anabilim Dalı, Yayınlanmamış Yüksek Lisans Tezi.

Türkiye'de Aile Değerleri Araştırması, ASAGEM, Ankara 2010.

Usluata, A. (1997). Iletişim. İstanbul: İletișim Yayınları.

Williamson, J. (2000). Reklamlarn Dili-Reklamlarda Anlam ve İdeoloji. Ankara: Ütopya Yayınevi.

Yüksel, A. H. (1990). İletişimin Toplumsal Boyutu Olarak Kitle İletişimi. Kurgu Dergisi, (7), ss. 9-38. 


\title{
The Impact of TV Series on Society (The Example of Karabük)
}

\begin{abstract}
The Mass Media in recent past in which the society is mainly targeted has become one of the substantial elements that has a tremendous effect on social change. In fact, it has a vital function to pass down cultural values from generation to generation when used for true objectives but, misusing this great means will be resulted in deterioration of children and youngsters in terms of personal development as well as corruption in the structure of family and society.

With the development of technology, television entered the house and television channels started to multiply. Considering that the first television broadcast situated in the United States in 1928, competition, which is one of the basic principles of capitalism since then, has shown itself in the media and has dominated the visual media. The media is one of the most important actors affecting the society in change. Therefore, visual media today is a consumer culture in its own right. The first product marketed by many television channels that serve the consumer culture is the television series.. The first television broadcasts in Turkey began in the year of 1968. Since then, the TV sets have been built in each house, the whole layout of the house has been designed according to these tools. It was broadcasted through a single channel until 1986, but it was not possible to follow the rate of growth of the channels after this date. Television and television series in particular have become a part of postmodern life. Since the series began to be at the center of life, culture, customs, habits, values, lifestyle and family structure have changed.

The key question of our study is whether the TV series broadcasted in Turkish TV stations are suitable for the cultural fabric of Turkish society and family? Where these imaginary stories bradcasted in a tiny box and consumed lead our society? Within the framework of our study, we will deal with the effect of TV series on Turkish society. We also discuss the changed values of the society and its relinquishment as a result of being exposed to the TV series and being victim of visual media which has become an instrument of modern capitalism.

Our public survey includes a group of male comprising 200 individuals, as well as female comprising 200 individuals which adds up to 400 respondents from different ages. The subjects who were surveyed were; 100 women, 100 men, 50 young women, 50 young men, 50 girls, 50 boys. We chose respondents from Karabük people by simple random technique.

In recent years, with the widespread use of the Internet, overuse of social media, new video surveillance platforms, especially YouTube, have emerged. Watching more than 1 billion hours of video per day on YouTube, watching videos broadcasted on the channels like television series point to the fact that television, whose ability to shape society is not controversial and which has millions of users, may lose its throne to the internet in the future.
\end{abstract}

Keywords: Social change, TV Series, Advertisements, Consumption. 